原著論文

\title{
口唇口蓋裂患者の補緅治療に関する一考察
}

\author{
野村 章子 河野 正司 野村 修一* \\ 櫻井 直樹 田中みか子 相澤 啓子
}

\section{A Study on the Prosthodontic Treatment for Cleft Lip and Palate Patients}

\author{
Akiko Nomura, Shoji Kohno, Shuichi Nomura*, \\ Naoki Sakurai, Mikako Tanaka and Keiko Aizawa
}

\begin{abstract}
Cleft lip and palate patients show several characteristic clinical and functional findings, such as :

a . Cross bite, open bite and unstable occlusion in ICP.

b. Tight upper lip, midface retrusion and scar contracted vestibular sulcus.

c. Malposition of teeth, oronasal fistula and velopharyngeal incompetence.

d. Relapse of teeth and segment.

To consider a prosthodontic therapy to be successful, two factors must be satisfied :

1. Reconstruction for optimum occlusion: stable occlusion in ICP and anterior guidance providing harmonious jaw movement.
\end{abstract}

2. Prosthesis must satisfy requests of esthetics, comfort, simplicity and durability.

In this study, the clinical and prosthetic findings of 10 patients before and after prosthetic treatment were compared.

Results :

1. All patients were satisfied with the given prosthodontic treatment.

2. In 2 patients, both factors were established.

In 4 patients who had anterior malocclusion, stable occlusion in ICP was established, but optimum anterior guidance was not.

In 4 patients who had severe malocclusion, optimum occlusion was not established with oral reconstruction.

3. Many patients who had upper malpositioned teeth, oronasal fistula, relapse of teeth and segment showed that their prostheses were more complicated and larger.

Therefore, we reconfirm that prosthodontists, oral surgeons and orthodontists must coordinate

新潟大学歯学部歯科補綴学第一講座 (主任：河野正司教授)

*新潟大学齿学部附属病院特殊歯科総合治療部（主任：河野正司教授）

Department of Removable Prosthodontics, School of Dentistry, Niigata University (Chief : Prof. Shoji Kohno)

*Polyclinic Intensive Oral Care Unit, School of Dentistry, Niigata University (Chief : Prof. Shoji Kohno)

平成 6 年 6 月 10 日受付 
and discuss how to accomplish a successful rehabilitation of cleft lip and palate patients.

Key words : cleft lip and palate, severe malocclusion, the principle of occlusion, prosthesis, team approach

\section{I. 緒言}

口唇口蓋裂患者の補綴治療は, 口腔外科, 耳鼻咽喉 科, 形成外科, 矯正科などで治療された後になお残存 する審美障害や，発音，咀嚼，曣下などの機能障害を 改善するために行われる。 そのため補綴科では，これ らの診療科による総合的で, 長期にわたる治療の最後 の段階を担当することになる.

ところで, 補緅治療では, 適正な咬合1)の再構成お よび補綴装置が審美性, 装着感, 単純性, 耐久性の諸 条件を充足することが一般的な要件といわれている。 一方, 口唇口蓋裂患者に対する補綴治療では, その効 果をあげる上で制約となる問題が，これまでに多々指 摘されている2

そこで今回，著者らがこれまでに担当した患者のう ち, 特に咬合の再構成が困難であった症例について, 診査と治療の内容を調査し，補綴治療における咬合と 補経装置に関する要件がどの程度まで充足されている かに焦点を絞って検討した. さらに, これらの要件を 満足する上で制約となる問題点を再確認し, その解決 法の一部を明らかにした。

\section{II. 調査対象と方法}

\section{1. 調查対象}

患者は, 新潟大学歯学部附属病院第 1 補綴科におい

Table 1 Information about patients 患者の情報

\begin{tabular}{|c|c|c|c|c|}
\hline \multicolumn{2}{|c|}{ Patients Age } & \multicolumn{3}{|c|}{ Sex Cleft-type Chief complaint } \\
\hline 1 & 23 & $\mathrm{~F}$ & UCLA & Esthetics \\
\hline 2 & 21 & M & UCLP & Esthetics, Speech \\
\hline 3 & 22 & M & UCLP & Esthetics \\
\hline 4 & 14 & $\mathrm{~F}$ & BCLP & Esthetics, Mastication \\
\hline 5 & 17 & $\mathrm{~F}$ & BCLP & Esthetics, Speech \\
\hline 6 & 18 & $\mathrm{~F}$ & BCLP & Esthetics, Mastication \\
\hline 7 & 17 & M & BCLP & Esthetics, Mastication \\
\hline 8 & 19 & M & BCLP & Esthetics, Speech, Mastication \\
\hline 9 & 17 & $\mathrm{M}$ & BCLP & Mastication \\
\hline 10 & 21 & M & UCLP & Esthetics, Speech \\
\hline Average & 18.9 & & & \\
\hline
\end{tabular}

て昭和 53 年から平成 5 年 9 月までに治療した口唇口 蓋裂患者で, 口腔外科, 耳鼻咽喉科, 矯正科で治療を 受けた後の補綴治療による咬合再構成が困難であった 男性 6 例, 女性 4 例, 初診時年齢は 14 歳から 23 歳 (平均 18.9 歳) の 10 例である（Table 1).

患者の裂型は片側性口唇裂 (unilateral cleft lip and alveolus, UCLA) が 1 例, 片側性口唇口蓋裂 (unilateral cleft lip and palate, UCLP) が 3 例, 両 側性口唇口蓋裂 (bilateral cleft lip and palate, BCLP) が 6 例であり, 主訴は審美障害, 発音障害, 咀嚼障害であった。

対象となる 10 例において, 症例番号 1 では口唇形 成術, 症例番号 8 では口唇形成術と口蓋形成術が施行 されていた. 残りの 8 例では, 口唇と口蓋の手術後 に, 矯正治療により歯の移動やセグメントの拡大が行 われていた。

\section{2. 調查方法}

三浦 ${ }^{10}$ が矯正医の立場から指摘した種々の問題点を 参考にして, 補綴科初診時の補緅治療に関連する 10 項目（Table 2-1，2-2） を調查項目とした.

対象となる 10 症例の治療内容の評価については, 患者の主訴が改善されたかどうかについて調べささら に術者の立場加咬合の再構成と補綴装置に求められ る要件がどの程度充足されたかについても調査した (Table 3-1，3-2). すなわち，(1) 臼歯部において, より安定した咬頭嵌合位が得られているか，(2) 側方 滑走運動を指導する適正な歯牙ガイドが犬歯，小白歯 部において再構成されているか，(3) 審美性, 装着感, 単純性，耐久性の諸条件を満足した補緅装置が装着さ れているかである。

調査に際しては, 補綴科診療録, 研究用模型, 口腔 内と口腔外の写真を使用した。

\section{III. 結 果}

\section{1. 診查所見について}

補緅科初診時の前歯部の被蓋関係では, 10 例中反 対咬合が 6 例，開咬が 3 例で，正常な被蓋関係を有す 
Table 2-1 Clinical Problems 臨床所見

\begin{tabular}{|c|c|c|c|c|c|c|c|}
\hline \multirow{2}{*}{ Patients } & \multicolumn{2}{|c|}{ Malocclusion } & \multicolumn{5}{|c|}{ Abnormal Appearance } \\
\hline & Anterior & Posterior & Abutment & Tooth & Upper Lip & Midface & Vestibular Sulcus \\
\hline 1 & Cross bite & - & Rotation, & Inclination & - & - & - \\
\hline 2 & - & Unstable occlusion in ICP & Inclination & & - & - & - \\
\hline 3 & Open bite & Lateral cross bite & & - & - & Retrusion & - \\
\hline 4 & Cross bite & Open bite & Rotation & & - & - & Scar contraction \\
\hline 5 & Open bite & Unstable occlusion in ICP & & - & - & Retrusion & - \\
\hline 6 & Open bite & Lateral cross bite & Rotation, & Dislocation & Tight & Retrusion & Scar contraction \\
\hline 7 & Cross bite & Total cross bite & Rotation, & Dislocation & - & Retrusion & Scar contraction \\
\hline 8 & Cross bite & Lateral cross bite & Rotation, & Dislocation & - & Retrusion & Scar contraction \\
\hline 9 & Cross bite & Open bite & Rotation, & Inclination & - & - & - \\
\hline 10 & Cross bite & Total cross bite & & - & Tight & Retrusion & Scar contraction \\
\hline
\end{tabular}

Table 2-2 Other Clinical Problems その他の臨床所見

\begin{tabular}{|c|c|c|c|c|}
\hline Patients & $\begin{array}{l}\text { Oronasal } \\
\text { Fistula }\end{array}$ & $\begin{array}{l}\text { Velopharyngeal } \\
\text { Incompetence }\end{array}$ & $\begin{array}{l}\text { Relapse of Tooth } \\
\text { and Segment }\end{array}$ & $\begin{array}{l}\text { Difficulty in } \\
\text { Continuing Therapy }\end{array}$ \\
\hline 1 & - & - & - & - \\
\hline 2 & - & - & + & - \\
\hline 3 & Narrow & - & + & Distance to the clinic \\
\hline 4 & - & - & + & $\begin{array}{l}\text { Time limitation by } \\
\text { studies }\end{array}$ \\
\hline 5 & Narrow & + & + & $\begin{array}{l}\text { Time limitation by } \\
\text { studies }\end{array}$ \\
\hline 6 & Narrow & - & + & Distance to the clinic \\
\hline 7 & Narrow & + & + & $\begin{array}{l}\text { Time limitation by } \\
\text { occupation }\end{array}$ \\
\hline 8 & Wide & + & - & - \\
\hline 9 & Narrow & - & + & $\begin{array}{l}\text { Time limitation by } \\
\text { studies }\end{array}$ \\
\hline 10 & Wide & - & + & - \\
\hline
\end{tabular}

Table 3-1 Prosthetic Approach and Evaluation 主な補緅治療内容とその評価

\begin{tabular}{rllcc}
\hline \hline \multirow{2}{*}{ Patients } & Prosthesis & \multicolumn{3}{l}{ Chief Complaint } \\
\cline { 3 - 5 } & & Esthetics, & Mastication, & Speech \\
\hline 1 & Crowns & Satisfying & - & - \\
2 & Crowns, Fixed bridge & Satisfying & - & Satisfying \\
3 & $\begin{array}{l}\text { Conus telescope denture } \\
4\end{array}$ & $\begin{array}{l}\text { Crowns, } \\
\text { Catisfying }\end{array}$ & - & - \\
5 & $\begin{array}{l}\text { Conus telescope denture } \\
\text { Crowns, Removable }\end{array}$ & Satisfying & Satisfying & - \\
6 & $\begin{array}{l}\text { partial denture (metal base) } \\
\text { Conus telescope denture }\end{array}$ & Satisfying & - & Satisfying \\
7 & $\begin{array}{l}\text { Removable partial denture } \\
\text { (resin base) }\end{array}$ & Satisfying & Satisfying & - \\
8 & $\begin{array}{l}\text { Removable partial denture } \\
\text { (resin base) }\end{array}$ & Satisfying & Satisfying & Satisfying \\
9 & $\begin{array}{l}\text { Removable partial denture } \\
\text { (resin base) }\end{array}$ & - & Satisfying & - \\
10 & $\begin{array}{l}\text { Removable partial denture } \\
\text { (metal base) }\end{array}$ & Satisfying & - & Satisfying \\
\hline
\end{tabular}

Table 3-2 Clinical Evaluation of Occlusal Reconstruction and Prosthesis 咬合の構築と補緅装置に対する臨床的評価

\begin{tabular}{|c|c|c|c|c|c|c|}
\hline \multirow{2}{*}{ Patients } & \multicolumn{2}{|c|}{ Occlusal Reconstruction } & \multicolumn{4}{|c|}{ Prosthesis } \\
\hline & Anterior & Posterior & Esthetics, & Comfort, & Simplicity, & Durability \\
\hline 1 & O (Natural dentition, crowns) & O (Natural dentition) & $\mathrm{O}$ & 0 & 0 & $\mathrm{O}$ \\
\hline 2 & (Fixed bridge) & (Crowns) & $\mathrm{O}$ & O & O & O \\
\hline 3 & $\triangle$ (Natural dentition) & (C.t.d.) & O & $\triangle$ & $\triangle$ & O \\
\hline 4 & $\Delta$ (C.t.d.) & O (Crowns, C.t.d.) & $\mathrm{O}$ & O & 0 & $\mathrm{O}$ \\
\hline 5 & $\Delta$ (Crowns, R.p.d.) & (Crowns) & $\mathrm{O}$ & $\triangle$ & $\triangle$ & $\mathrm{O}$ \\
\hline 6 & (c.t.d.) & (c.t.d.) & $\mathrm{O}$ & $\triangle$ & $\triangle$ & O \\
\hline 7 & $\times$ (R.p.d.) & $\times$ (R.p.d.) & O & $\triangle$ & $\triangle$ & $\triangle$ \\
\hline 8 & $\times$ (R.p.d.) & $\times$ (R.p.d.) & 0 & $\triangle$ & $\triangle$ & $\triangle$ \\
\hline 9 & $\times$ (R.p.d.) & $\times \quad$ (R.p.d.) & $\triangle$ & 0 & 0 & $\triangle$ \\
\hline 10 & $\times \quad$ (R.p.d.) & $\times$ (R.p.d.) & 0 & $\Delta$ & $\triangle$ & 0 \\
\hline
\end{tabular}

$\mathrm{O}:$ Optimum, $\Delta:$ Incomplete, $\times:$ Unaccomplished

C.t.d. : Conus telescope denture

R.p.d. : Removable partial denture 


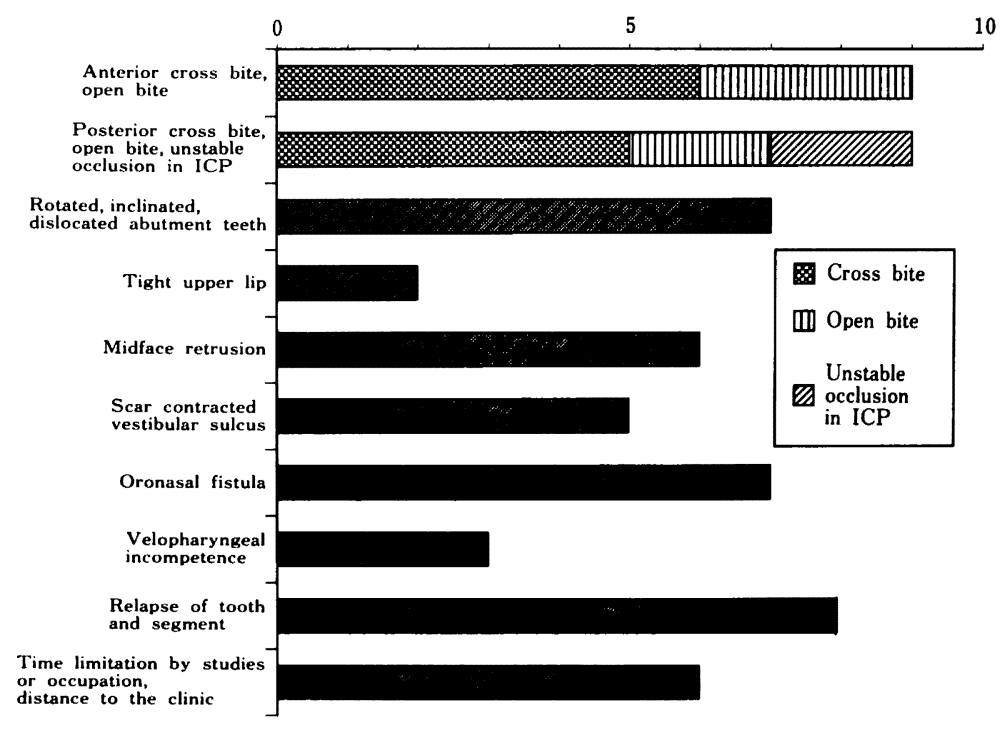

Fig. 1 Number of Patients with the following problems 各々の所見が認められた患者の数

る症例はわずか 1 例であった（Table 2-1, 2-2, Fig. 1).

臼歯部の咬合関係については, 10 例中反対咬合が 5 例, 開咬が 2 例, 不安定な咬頭嵌合位が 2 例で, 安 定した咬頭嵌合位を有する症例はわずかに 1 例であっ た.

この他に, クラウンや橋義歯の支台歯と可撤性義歯 の鉤歯に歯軸傾斜, 捻転, 転位が認められた症例が 7 例, 鼻下部の宿凹が 6 例, 口腔前庭の疲痕収縮が 5 例，残遺孔が 7 例と，多くの症例において補緅治療を 行う上で問題となる所見が認められた。 また, 矯正治 療による歯の移動やセグメントの拡大を行った 8 例に おいては, 後戻りの可能性があった.

さらに, 勉学や就職への配虑が必要であったり, 遠 隔地からの通院で, 治療日に制約のある患者が多かっ た.

一方, 上唇の緊張が 2 例, 鼻咽腔閉鎖不全が 3 例に 認められ, 前述の所見に比べるとその例数は少なかっ た.

\section{2. 治療内容と治療効果について}

1）補緅装置について

製作した補緅装置の種類については Table 3-1 に示 すように, クラウンのみが 1 例, クラウンと固定性橋 義歯が 1 例, 可撤性義歯のみが 6 例, クラウンと可撤 性義歯が 2 例であった．可撤性義歯を装着した 8 例中
コーヌス・テレスコープ義歯が 3 例，金属床義歯が 2 例，レジン床義歯が 3 例であった.

治療後, すべての症例において主訴が改善され, 患 者の満足が得られた。ところが, 補綴装置に求められ る審美性, 装着感, 単純性, 耐久性のすべての条件を 満足した例数は 10 例中わずかに 3 例であった (Table 3-2).

なお, 実際の治療手順と追加説明は次項 3 で述べ る.

2）再構成された咬合について

咬合の再構成の程度については, 以下に示すとおり であった（Table 3-2).

(1) 咬頭嵌合位について

安定した咬頭嵌合位が再現された症例は，10 例中 6 例であった. 症例番号 1 では，すでに天然歯による 咬頭嵌合位が獲得されていたため，臼歯部の補緅装置 が不要であった。症例番号 2,5 の 2 例ではクラウン により, 症例番号 3,6 の 2 例ではコーヌス・テレス コープ義歯により, さらに症例番号 4 ではクラウンと コーヌス・テレスコープ義歯によりそれぞれ安定した 咬頭嵌合位が得られた。

しかし, 残りの 4 例（症例番号 7,8,9,10）で は, 上䅡歯列弓が著しく狭窄しているために，クラウ ンやコーヌス・テレスコープ義歯の外冠では正常な被 蓋関係と安定した咬頭嵌合位を付与できなかった。 
（2）側方運動の歯牙ガイドについて

安定した咬頭嵌合位が得られた 6 例中, 症例番号 1 では天然歯で適正な歯牙ガイドが既に獲得されていた ので，歯軸傾斜と捻転が認められた $1 \mid 12$ を歯冠修 復する際には審美性の改善のみならず, 適正な歯牙ガ イドの確保にも留意した.

症例番号 2 では固定性橋義歯により, 症例番号 6 で はコーヌス・テレスコープ義歯により咬合障害が発生 しない歯牙がイドを付与することができた. なお，症 例番号 6 の場合は, 歯牙ガイドを与える人工歯を支台 歯から離れた位置に配列したので, 人工歯のガイドを 少し緩くして義歯の安定を優先した。

歯の位置不正が認められた 3 例中, 症例番号 3 の右 側犬歯, 小臼歯部のオーバー・バイト量は不足してい た.しかし，健全な天然歯を保存することを優先した ので, 歯冠修復しなかった。 また, 症例番号 4, 5 の 両側犬歯, 小罒歯部では補綴的に十分なオーバー・バ イト量を与えると臨床的歯冠長が増し, 支台歯の歯周 組織への障害が心配された。したがって，これらの症 例において，適正なガイドは与えられなかった。

歯の位置不正が著しい症例番号 7,8,9，10 の 4 例 では，下顎歯に対し上顎歯がかなり内方に位置し，補 緅的にも安定した咬頭嵌合位と適正な歯牙ガイドを再 構成できなかった。

これらの症例について, 有歯顎における適正な咬合 の再構成を客観的に評価すると，上述のように多くの 問題が明らかになった。しかし，患者が訴えていた審 美, 咀嚼, 発音障害に対する患者の主観的な評価は十 分に満足のいくものであった。

\section{3. 症例の概要と治療経過について}

次に, 裂や歯の位置不正の程度，口腔内外の組織の 状態の相違により固定性補緅装置や, コーヌス・テレ スコープ義歯, レジン床義歯, 金属床義歯などの可撤 性補経装置のいずれかを装着した 5 症例を選び,（1） 術前の問題点, (2) 補綴処置の特徴, (3) 術前の問題点 が解决できた点と処置後の問題点の各項目について記 してみたい.

\section{1) 症例 2}

21 歳男性, 右側口唇口蓋裂, 主訴は審美・発音障害 であった (Table 1).

(1) 術前の問題点

a . 42124 に歯牙欠損が認められた. 上下顎両 側犬歯の被蓋関係が正常で, 両側臼歯部の被蓋関係が
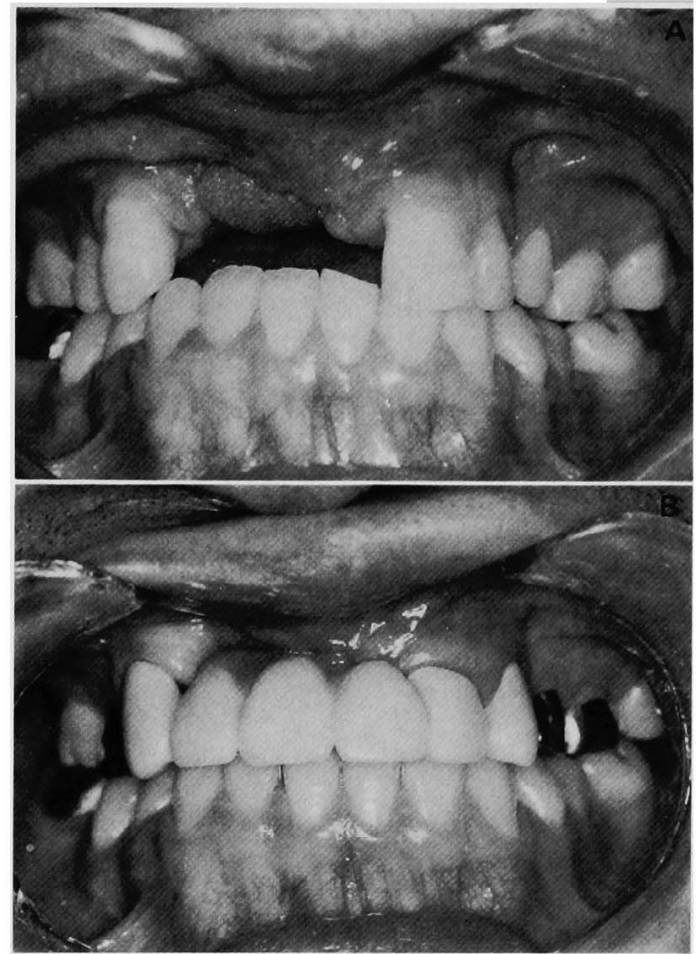

Fig. 2 A Patient 2. Unilateral cleft lip and palate case. $2 \mathrm{~B}$ Fixed bridge in position.

2 A 片側性口唇口蓋裂症例

2 B 固定性橋義歯の装着状態

ほほ正常であるにもかかわらず，咬頭嵌合位での咬合 接触は不安定であった（Table 2-1, Fig. 2 A).

b. 上顎歯の歯軸傾斜, 矯正治療により移動した歯 の後戻りの可能性があった（Table 2-2).

(2) 補綴処置の特徴

a . 前歯欠損による審美性の回復と発音障害の改 善, 安定した咬頭嵌合位の回復と歯の後戻りの防止を 目的として, クラウンと固定性橋義歯を装着した (Table 3-1, Fig. 2 B).

b. 上顎右側の第 2 小臼歯から左側の第 1 大臼歯ま でを橋義歯の支台歯に含めることにより，この範囲に 含まれる歯を連結固定した。な招，支台歯形成に先立 ち, 前歯部の歯牙ガイドを咬合器の調節機構に再現 し, これを参考にして橋義歯に滑走運動時の咬合接触 を付与した。

c.この症例では, 残遺孔を閉鎖するために舌粘膜 弁移植が行われていた. 欠損部粘膜の大部分を占める 舌粘膜は可動性の上唇粘膜に移行しているために, 発 音時その形態が容易に変化したので, ソフトワックス 

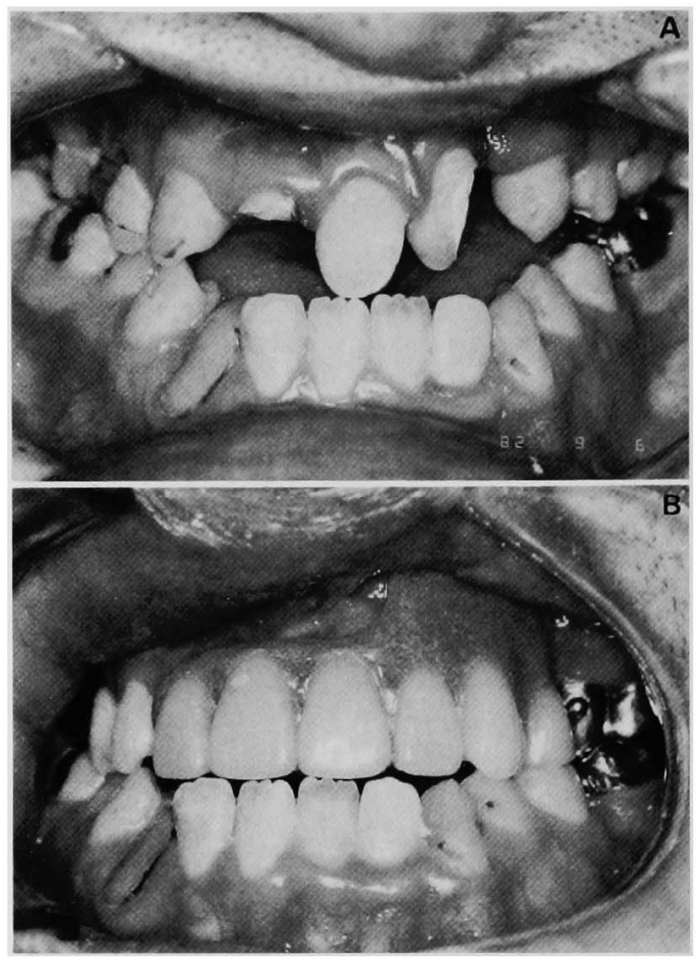

Fig. 3 A Patient 3. Unilateral cleft lip and palate case. Anterior open bite. Posterior cross bite.

$3 \mathbf{B}$ Conus telescope denture in position.

$3 \mathbf{A}$ 片側性口唇口蓋裂症例 前歯部の開咬, 臼歯部の反 対咬合

3 B コーヌス・テレスコープ義歯の装着状態

を用いて発音を指示しながらポンティック基底面の形 態を印象採得した。

（3）術前の問題点が解決できた点

a. 審美性ならびに安定した咬頭嵌合位と適正な 歯牙ガイドが, 小型で固定性の補綴装置（クラウン・ 橋義歯）により良好に回復され, 発音障害も改善され た. すなわち, 適正な咬合の再構成と補経装置に要求 されるすべての条件を満足した (Table 3-2).

2) 症例 3

22 歳男性, 左側口唇口蓋裂, 主訴は審美障害で あった（Table 1).

(1) 術前の問題点

a . $7 / 24$ に歯牙欠損が認められた. 上顎前歯部の 被蓋関係では, 顎裂部に隣接する左側中切歯, 犬歯は 開咬の状態で, 右側中切歯は切端咬合, 右側犬歯, 第 1 小臼歯の垂直的被蓋量は少なく, 両側とも適正な曾 牙ガイドは回復されていなかった，また，右側第 1 小
38 巻 6 号 (1994)

臼歯と左側第 2 大臼歯を除いた部位の咬合関係は反対 咬合であった（Table 2-1, Fig. 3 A).

b，鼻下部の陥凹，残遺孔，歯とセグメントの後戻 りの問題があった.

c . 遠隔地からの通院で治療日の制約があった (Table 2-2).

(2) 補綴処置の特徵

a . 適正な歯牙ガイドを与え, 鼻下部の豊隆を回復 するために，前歯部人工歯を残存歯の唇側に配列した 義歯を装着した（Table 3-1, Fig. 3 B).

b. 義歯はコーヌス・テレスコープ義歯で, 歯牙ガ イドの付与の他に, 臼歯部の咬頭嵌合位の確立, 残遺 孔の閉鎖および後戻りの防止をはかった.

（3）術前の問題点が解決できた点と処置後の問題点

a 、前歯欠損部の審美性と安定した咬頭嵌合位が回 復された。

b.しかし，健全な歯の切削を避ける目的で歯冠修 復しなかった右側犬歯と右側第 1 小臼歯の歯牙ガイド については十分には確立されなかった。

さらに, 遠隔地から通院していたために, 矯正治療 を再度行い適正な歯のガイドを付与する可能性につい て再検討し，実行するための時間的ゆとりがなかっ た.

c . 義歯は審美性, 耐久性を満足したが, 多数の銁 歯を含むためにその形態が複雑となり,さらに, 発音 機能に密接な関わりのある口蓋を部分的に被覆する結 果となった（Table 3-2).

3) 症例 6

18 歳女性, 両側性口唇口蓋裂, 主訴は審美・咀夁障 害であった（Table 1).

(1) 術前の問題点

a . $42 \mid 123$ に歯牙欠損が認められ，前歯部は開 咬, 臼歯部は反対咬合を呈していた（Table 2-1, Fig. $4 \mathrm{~A}$ ).

b . 上顎前歯部の捻転と転位, 上口唇の緊張, 鼻下 部の著しい陥凹, 口腔前庭の緳痕収縮, 残遺孔およ び, 歯とセグメントの後戻りの問題があった.

c. 遠隔地からの通院で治療日に制約があった (Table 2-2).

（2）補綴処置の特徵

a . 前歯部の開咬を改善し鼻下部の豊隆を回復する ために, 人工歯を顎堤から約 $5 \mathrm{~mm}$ 唇側に配列し, 休 翼の厚みを十分にとった（Table 3-1, Fig. 4 B).

b. 咬頭嵌合位の確立, 残遺孔閉鎤, 後戻りの防止 


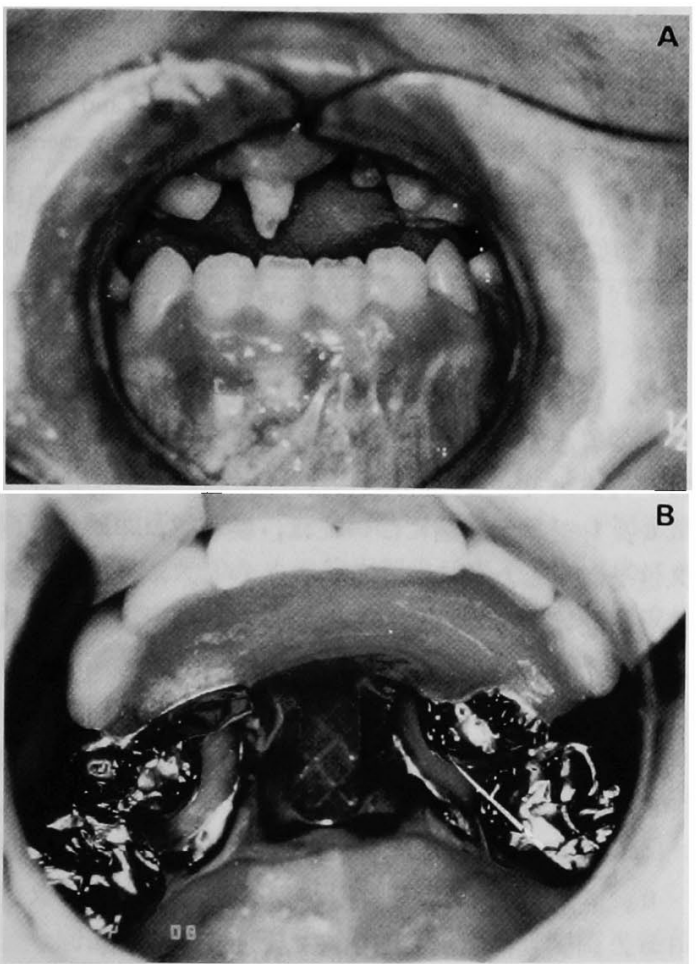

Fig. 4 A Patient 6. Bilateral cleft lip and palate case. Anterior open bite. Posterior cross bite. Scar contracted vestibular sulcus.

4 B Conus telescope denture with a fistula obturator in position.

$4 \mathrm{~A}$ 両側性口唇口蓋裂症例 前歯部の開咬, 刍歯部の反 対咬合

$4 \mathrm{~B}$ 残遺孔閉銷床を兼かるコーヌス・テレスコープ義歯 の装着状態

のために, 口蓋を被うコーヌス・テレスコープ義歯を 装着した。

（3）術前の問題点が解決できた点と処置後の問題点

a 、コーヌス・テレスコープ義歯により, 前歯部の 審美性と安定した咬頭嵌合位が回復された。

b . 健全な歯が存在しなかったので, 人工歯で歯牙 ガイドを付与しなければならなかった，その際に，審 美性を回復するために人工歯を支台歯より唇側に配列 したので, 義歯の安定を優先させて人工歯のガイドは 少し緩くした。

c.この症例では，すでに行われた外科治療と矯正 治療による改善がこれ以上望めないと判断されてい た。したがって，補緅装置は審美性と耐久性を満足し たが, 治療後に残った多くの問題点を改善するため に，複雑で大型の可撤性補経装置を装着しなければな
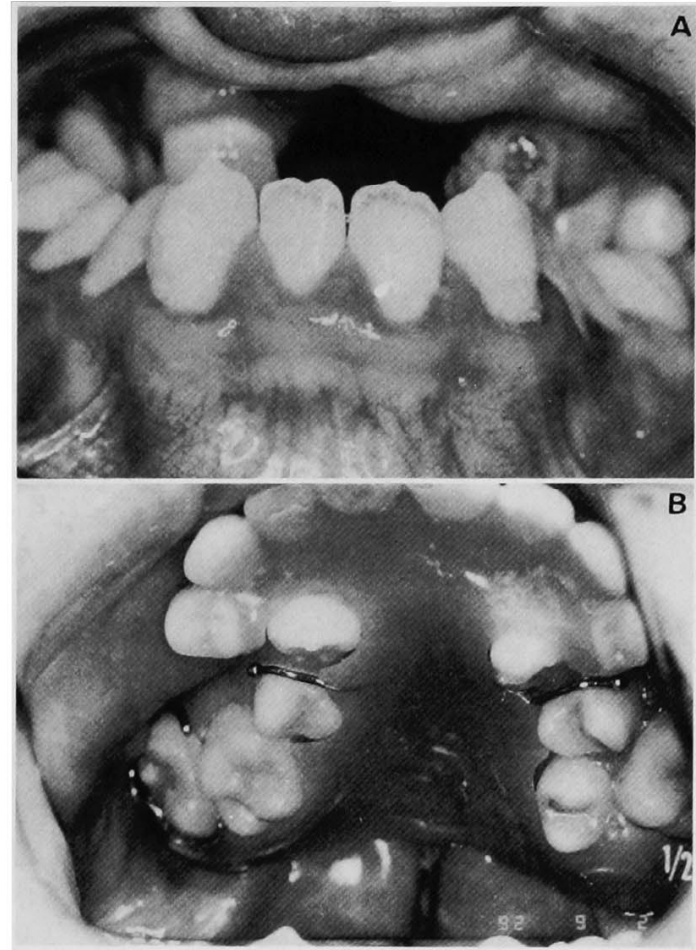

Fig. 5 A Patient 8. Bilateral cleft lip and palate case. Anterior and posterior cross bite. Severe malpositioned teeth. Scar contracted vestibular sulcus.

5 B Removable partial denture with a speech bulb in position.

$5 \mathrm{~A}$ 両側性口唇口蓋裂症例 前歯部と芷齿部の反対咬 合, 歯の著しい位置不正, 口腔前庭の痽痕収縮

5 B スピーチ・バルブが連結された可撤性部分床義歯装 着状態

らなかった（Table 3-2）。

4) 症例 8

19 歳男性, 両側性口唇口蓋裂，主訴は審美・発音・ 咀嚼障害であった（Table 1)。

(1) 術前の問題点

a . 421|12 に歯牙欠損が認められ，上下顎歯列 弓は著しく狭窄し，歯の位置不正も顕著であった (Table 2-1, Fig. 5 A).

b. 鼻下部の陥凹, 口腔前庭の瘢痕収縮, 残遺孔, 鼻咽腔閉鎖不全の問題があった（Table 2-2).

c .耳鼻咽喉科で口唇と口蓋の形成術を受けた後 は，口腔外科でスピーチエイドを製作した以外に，治 療に対する患者の協力が十分に得られなかった。

（2）補緅処置の特幑

a 、治療の必要性を十分に説明し，患者の同意が得 


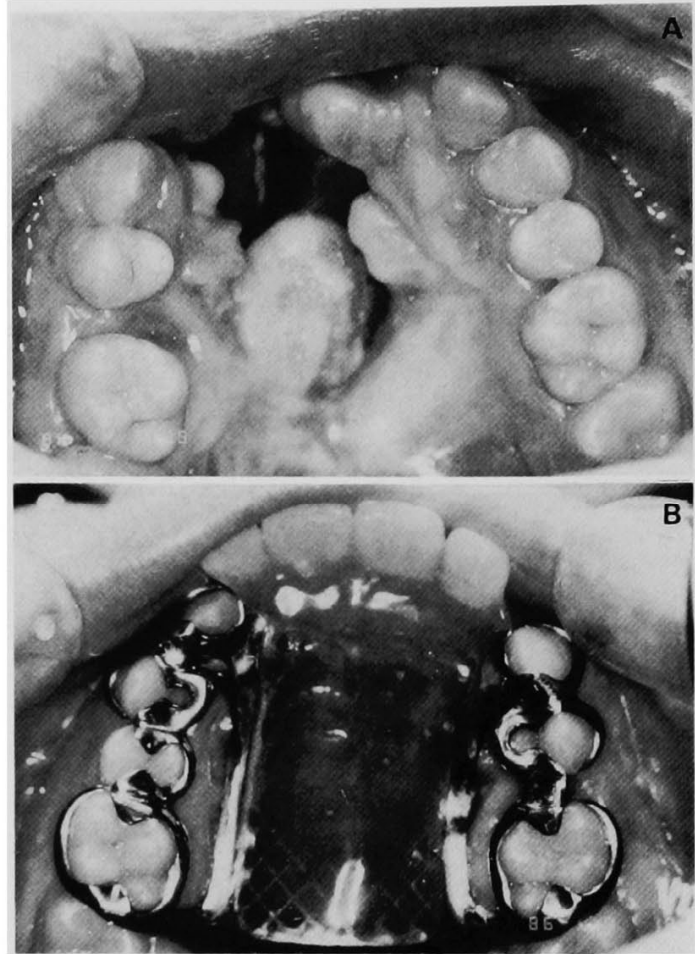

Fig. 6 A Patient 10. Unilateral cleft lip and palate case. Wide oronasal fistula.

6 B Removable partial denture with a fistula obturator in position.

6 A 片側性口唇口蓋裂症例 大きな残遺孔

6 B 残遺孔閉鎖床を兼ねる可撤性部分床義歯の装着状態

られたことを確認した後に，口腔外科の協力によりス ピーチエイドを組み入れたレジン床義歯を装着した (Table 3-1, Fig. 5 B).

b ．義歯の製作にあたり，鼻下部の豊隆と前歯部の 被蓋関係を回復するために, $4+4$ の唇側に人工歯 を二重配列した。

c. 残遺孔を確実に封鎖するために，完成義歯の前 歯部床縁と口蓋部の床内面を印象用ワックスで印象採 得し、リライニングを行った。

d．矯正科においてマルチブラケット治療を予定し ているために，義歯の改造が容易なレジン床を選択し た。

（3）術前の問題点が解決できた点と処置後の問題点

a 、レジン床義菌の装着により，審美性が回復さ れ，咀唃障害と曣下障害が改善された。しかし，歯の 位置不正が著しいために適正な咬合を付与することが できなかった。
Table 4 Factors for successful prosthodontic therapy 補緅治療の要件

1. Reconstruction for stable occlusion in ICP and ante rior guidance providing harmonious jaw movement.

2. Prosthesis must satisfy requests of esthetics, comfort, simplicity and durability.

b．この患者については，今後矯正治療を予定して いるので, 歯の位置不正を改善した後により適正な咬 合が再構築できると思われた。

c 、レジン床義歯については, 装着感, 単純性, 而 久性を満足したとはいえない，しかし，矯正装置の装 着を可能にするためにはやむを得ない設計と考えられ た (Table 3-2).

5) 症例 10

21 墄男性, 右側口唇口蓋裂, 主訴は審美・発音障害 であった (Table 1).

(1) 術前の問題点

a . 521|12 に歯牙欠損が認められた.

b. 両側犬歯部加ら自歯部に至る反対咬合.

c. 口蓋中央部から顎裂部に及ぶ広範囲の残遺孔が 認められた．矯正治療により雪の移動は可能であった が，この残遺孔が存在するために上額歯列弓を拡大す ることと, 残遺孔の外科的閉鎖は不可能であった (Table 2-1, 2-2, Fig. $6 \mathrm{~A}$ ).

d．上唇の緊張，鼻下部の著しい陥凹，口腔前庭の 瘢痕収縮, 歯の後戻りの問題があった。

（2）補綴処置の特徵

a . 健全な上額犬歯，小臼歯，大臼歯については歯 冠修復せずに保存した（Table 3-1，Fig. 6 B).

b. 広範囲の残遺孔を閉鎖するために，口蓋床を有 する金属床義歯を装着した。また義歯の連続鉤による 二次固定で歯の後戻りを防止した。

（3）術前の問題点が解決できた点と処置後の問題点

a ．金属床義歯により，審美性の回復と発音障害の 改善が可能となった，しかし，上額犬歯，小臼歯，大 臼歯が健全であることと，矯正治療による歯列弓の拡 大が不可能な理由から，反対咬合を改善し，適正な咬 合を与えることができなかった。

b. 口蓋床と連続鉤を含む設計上，義歯に求められ る装着感，単純性を満足することができなかった (Table 3-2). 


\section{IV. 考察}

口唇口蓋裂患者の補緅治療を難しくしている事柄を 再確認する目的で, 当科で補緅装置を装着した症例の 補緅科初診時の所見と治療内容について, 一般的な補 緅治療における咬合と補経装置に関する要件（Table 4）から検討した.

\section{1. 適正な咬合の回復}

著者らは, 有歯顎歯列における咬合が臼歯部での安 定した咬頭嵌合位と, 咬合障害を起こさない下䫇の滑 らかな滑走運動のための前歯部歯牙ガイドから構成さ れなければならないと考えている111). 咬合の構成体 は天然歯が最良であるが, 歯冠崩壊, 歯の位置不正, 歯牙欠損を伴う症例では, 天然歯から歯冠修復物や人 工歯に置き換わることになる，特に，咬合の構成体が 人工歯の場合には, 義歯床の安定性や人工歯の摩耗の 面から, 適正な咬合を付与する上で困難な点があると 考えられる。

今回選んだロ唇口蓋裂患者 10 例の治療内容を評価 したところ，すへての症例において主訴が改善され， 患者の満足が得られた。ところが，これらの 2 つの条 件を満足した症例はわずかに 3 例であった。他の 7 例 中, 3 例では安定した咬頭嵌合位が再構成されたにも かかわらず, 前雬部ガイドが確実には与えられていな かった.

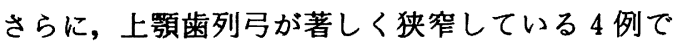
は, 全顎的な補綴装置を装着したにもかかわらず, 適 正な咬合が与えられていなかった。

そこで,この種の患者に対して咀嚼・発音機能と審 美性の改善を目的とする, よりレベルの高い補綴治療 を行うための対応策を, 次項において考察してみた い.

1）前歯部の被蓋関係について

審美性と発音機能を回復するためには，前歯部の被 蓋関係に対する配慮が必要である。とりわけ，枵裂部 の欠損補緅と, 前歯部の反対咬合や開咬の改善が重要 となる。

ところが, 前歯部の被蓋関係には, 審美性と発音機 能以外に歯牙ガイドとの密接な係わりがあることにも 着目しなければならないと思われる。

2）側方滑走運動の歯牙ガイドについて 外科治療や, 矯正治療により犬歯を含めた前歯部に
適正なオーバー・バイトとオーバー・ジェットが与え られているならば，天然歯による歯牙ガイドは補綴治 療前にすでに確立されているわけである。しかしなが ら,オーバー・バイト量が不足すると, 見かけ上の被 蓋関係が付与されるだけで，臼歯部の咬合障害を起こ さない歯牙ガイド ${ }^{11}$ が獲得されているとは言い難い.

今回の調査では, 補綴治療の開始時に適正な歯牙ガ イドを有している症例は 10 例中わずかに 1 例（症例 番号 1 ）であった. 片側あるいは両側に残存する犬歯 や小臼歯のオーバー・バイト量が不足し軽度の開咬と なっていたり, 軽度の反対咬合となっていた症例番号 $3 ， 4 ， 5$ においては，限界はあるとしても，歯の移動 で適正な被蓋関係を与えることが可能であったなら ば，橋義歯の支台歯となる場合を除いて，補緅装置に よらない天然歯による歯牙ガイドを確立することがで きたのではないかと考えられた。

補緅治療に先だって行われる歯やセグメントの動的 移動の段階で, より適正な咬合の確立にも注目して, 治療内容についての他科と補緅科とによる連携が確 実，かつ具体的になされたならば，この問題は多少な りとも解決できたのではないかと考えられた。つま り, Henry, Tanが示したDiagnostic wax-up and

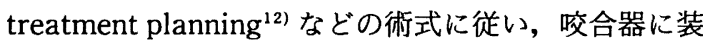
着した研究模型上に，適切な歯牙ガイドを与えるため に必要とする被蓋関係と，矯正移動によって予測され る被蓋関係をそれぞれ具体的に明示すれば解決できる と思われる症例（症例番号 $3 ， 4 ， 5 ）$ が存在した。

3） 臼歯部の咬合関係について

臼歯部での安定した咬頭嵌合位とは，雨牙要素とし ては咬頭と小窩が安定した嵌合関係を保ち，顎関節㸗

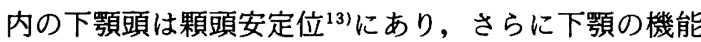
運動の開始点ならびに終末位としての役割を具備する ことである.

今回の調査では顎関節部について調査できなかった が, それ以外の点においては，調査した 10 例の中で， 補緅治療前にこの条件を満足した症例は，口唇裂を呈 するが口蓋裂のない 1 例（症例番号 1 ）であった。

しかし一方, 三浦 ${ }^{10}$ は一般の不正咬合者に比して, この種の患者に歯の形成不全, 特にエナメル質減形成 が多くみられると報告している，今回調査した症例に おいても, エナメル質減形成に起因する平坦な咬頭が 多くの歯に認められた.この所見に加え, 上顎歯列弓 の狭窄もみられた 9 例の咬頭と小窩との嵌合状態は不 十分なものであった。 
これらの症例のうち，上顎歯列弓の狭窄が軽度で あった症例番号 2,5 の 2 例は歯冠修復で, 症例番号 $3 ， 4 ， 6$ の 3 例はコーヌス・テレスコープ義歯で安定 した咬頭嵌合位を確立することができた。一方，上顎 歯列弓の狭窄が著しく，臼歯部の反対咬合や開咬を呈 した 4 例（症例番号 $7,8,9,10$ ） は，天然歯や顎堤 から唇煩側に配列した人工歯歯列弓によって，下顎歯 列弓との大きさの不一致をかろうじて修正できた．と ころが，咬頭嵌合に関与できない歯は銁歯やオー バー・デンチャーの支台歯として活用する以外に方法 がなかった。

\section{2. 補綴装置について}

今回調査した症例では, 補綴装置が審美性, 装着 感，単純性，耐久性の諸条件を満たす上で制約となる 問題点が多かったために，すべての条件を満足した例 数はわずかであった.

1）鉤歯，支台歯における問題点

歯の歯軸傾斜，捻転，転位は，審美性に支障がある ばかりではなく，補綴装置の維持歯とする際にも好ま しくない。それらの程度が特に著しい症例では, 補経 治療を行う上で便宜抜髄（症例番号 1，2）や，オ一 バー・デンチャー（症例番号 6，9）で対応しなければ ならないことがあった。

補経装置の諸条件を重視する立場では，補綴治療を 始める前にこれらの問題をできるだけ改善してもらえ れば，さらに良好な治療結果が得られると思われる。

2）周囲軟組織における問題点

上唇の緊張, 鼻下部の陥凹, 口腔前庭の疫痕収縮に ついては, 補緅装置の前歯部人工歯の配列位置と, 床 翼の形態を決定する際に十分な配慮が必要であった。 蠟義歯の試適時に，これらの事項を確認することはも ちろん，診査時にすでに義歯の外形を予測しておくこ とも必要であると考えられる。

3） 口腔内組織における問題点

（1）残遺孔については，その大きさと位置により補 綴装置の種類が決定される. 欠損歯が少ないにもかか わらず口蓋に存在する広範囲な残遺孔を閉鎖するため に，やむなく口蓋床を含む金属床義歯を装着しなけれ ばならない症例があった（症例番号 10).

（2）鼻咽腔閉鎖不全を有する症例は 10 例中 3 例と 比較的少数であった。症例番号 7,8 の 2 例は補綴装 置が可撤性レジン床義歯であったので，スピーチ・エ イドを連結する点においては問題とならなかった。
症例番号 5 においては, 前歯欠損が 3 歯と少なく, 残遺孔が口腔前庭部に限局していたために, 固定性補 綴装置の適応と考えた。しかし，スピーチ・エイドを 連結する必要性から，可撤性の床義歯を装着しなけれ ばならなかった。

$\mathrm{B} \phi \mathrm{hn}^{2)}$, Ramstad ${ }^{3)}$, Kantorowicz ${ }^{14)}$, Ohyama ${ }^{15)}$, 谷口ら ${ }^{5)}$, 鈴木ら ${ }^{16)}$ は, 口唇, 口蓋裂患者の補綴装置 には固定性のブリッジが最も望ましいと述べている. ところが，欠損歯が少なくても残遺孔が存在していた り，鼻咽腔閉鎖機能不全がある場合に，ややもすると 可撤性の床義歯で対処してしまう場合が，日常臨床に おいて見受けられる。

Ohyama ${ }^{15)}$ は無床タイプのコーヌス・テレスコープ 義歯に, Ramstad ${ }^{3)}$ は橋義歯に残遺孔の閉鎖のための オブチュレータを組み込んだ手法を報告している。わ れわれも, 今後は, 橋義歯あるいは, 無床タイプの コーヌス・テレスコープ義歯にオブチュレータやス ピーチ・エイドを着脱可能にする装置を検討し, 補経 装置の装着感, 単純性, 耐久性の向上に心がけたい.

4）歯やセグメントの後戻りの問題点

歯やセグメントの後戻りも補綴治療を制約する事項 である.どの程度の後戻りが起こるかを明確に把握す

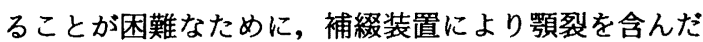
どの部位までを連結固定しなければならないかについ て迷うことが多々ある.

福原ら ${ }^{17}$ は，34 名の口唇，口蓋裂患者について矯 正治療による上顎歯列弓の拡大の程度と, 保定中と保 定後 1 年以上経過した時期における後戻り量との関連 について報告している。 また，武藤ら ${ }^{18}$ は，外科的に 拡大した 7 名の同種の患者について, 歯列弓の拡大量 と 1 から 4 年間に生じた後戻り量を報告している。さ らに, 連結固定の範囲を予測, 判断する上で見落とし てはならない臨床的要因について, Ramstad ${ }^{3)}$, 大 $山^{199}$, 谷口ら ${ }^{5)}$ は，(1) 矯正治療による歯列弓の拡大 量と歯の移動量, (2) 外科的治療による口蓋痏痕の程 度，(3) 保定の期間，(4) 対合歯との嵌合関係が重要な 点であると述べている.

このように, 後戻りの可能性や臨床的要因を考慮す るならば，歯やセグメントの後戻りを防止するために 有効とされるリジッドなコーヌス・テレスコープ義 歯"装着することは, 今回調査した症例においても 十分に妥当であったと思われる。

一方, この種の補綴装置は複雑, 大型化する傾向が あるために, 装着感, 単純性の条件から逸脱すること 
も多い. この点については, 谷口ら5), 田中ら ${ }^{20)}$ 同 様の意見を述べている.

そこで, 前述の 4 項目の臨床的要因に基づいた検討 を矯正科, 口腔外科, 補経科が共同で行うことは, 強 固な連結固定が必要な症例を決定し, 連結固定の範囲 を明らかにする点において必須のことである。

5）来院条件について

口腔外科治療や矯正治療が終了し, 補綴治療を開始 する時期が 20 歳前後で, 進学や就職の時期に一致す る症例が多かった. また, 近郊に適切な医療センター がないために，遠方から来院する患者も見受けられ た. 特に, 大がかりな治療を必要とする患者で, 上記 の理由から, 治療時間が制約されたり, より良い咬合 を確立するために外科治療や矯正治療を勧めることが 無理な場合があった。

この点については, 治療計画を患者や家族に十分に 説明し, 患者の協力のもとで最大限の努力を払うこと が肝要であろう。

\section{3. チームアプローチの重要性}

近年, 出生直後の段階において Hotz 床による的確 な顎発育の誘導がなされ，その後適切な時期に裂の閉 鎖術20 23)が施行されている。これらの治療法により 良好な澦発育誘導がなされているので, 補綴治療で適 正な咬合を再構成する立場からも, 今後の治療効果に 対し大いに期待したい.

また，矯正科，口腔外科，補緅科の各専門医による 総合治療の開始前, 術中, 術後に行う咬合診断の重要 性を強調したい. 加えて, 今回明らかとなった知見を もとに, 平成 3 年度 4 月より発足した, 当附属病院の すべての診療科の専門医で構成されている口蓋裂診療 班の活動において, より効果的な治療に関する十分な 協議の場を持ちたいと考えている.

\section{V. 結 論}

口唇口蓋裂患者の補綴治療を難しくしている問題点 を明確にする目的で, 本学附属病院第 1 補綴科で治療 した患者の中から咬合再構成が困難であった 10 症例 の診査時所見と治療内容を補綴治療の要件から検討 し，以下の知見を得た。

1. 調査した 10 例のうち, 治療後に適正な咬合す なわち, 安定した咬頭嵌合位と咬合障害を起こさない 下顎の滑らかな滑走運動のための歯牙ガイドを付与で
きた症例はわずかに 3 例であった.

前歯部の不正咬合を有する 3 例では, 安定した咬頭 嵌合位が再構成されていても適正な歯牙ガイドが付与 されていなかった。また，著しい不正咬合を有する 4 例では，全顎的な補綴装置を装着したにもかかわら ず，適正な咬合が与えられていなかった。

2. 審美性, 装着感, 単純性, 耐久性の諸条件を満 足する補緅装置を装着する上で制約となる問題が多く みられた．特に，歯の歯軸傾斜や捻転，残遺孔，歯や セグメントの後戻りは, 補綴装置を複雑, 大型化する 傾向が強かった.

3. これらの要件を満足する補綴治療を行うため に, 口腔外科, 矯正科, 補綴科が中心となって協議さ れる総合診断の重要性を再確認した。

本論文の要旨は, 平成 5 年度新潟歯学会第 2 回例会 (1993 年 11 月）にて発表した.

\section{文献}

1）河野正司：補綴学の立場から考えた有歯顎咬合の原則, The Quintessence, $11: 87 \sim 95,1992$.

2) $\mathrm{B} \phi \mathrm{hn}, \mathrm{A} .:$ Prosthetic problems in the treatment of jaw clefts, Trans Europ Orth Soc, $43: 399 \sim 409,1967$.

3) Ramstad, T. : Post-orthodontic retention and postprosthodontic occlusion in adult complete unilateral and bilateral cleft subjects, Cleft Palate J, 10:34 50, 1973.

4) Beumer, J. III, Curtis, T.A. and Firtell, D.N. : Maxillofacial rehabilitation-Prosthodontic and surgical considerations, 292 310, The C.V. Mosby Company, Saint Louis, 1979.

5）谷口 尚, 大山喬史, 水野行博 : 唇䫟口蓋裂患者の補緅, 補緅誌, $26: 109 \sim 129,1982$.

6）野村修一, 石岡 靖: 口蓋裂患者の補綴治療, 歯科ジャー ナル, $17: 305 \sim 315,1983$.

7) 大山喬史, 大畑昇:唇顎口蓋裂患者の補緅, The Dental, $2: 431 \sim 445,1984$.

8）田辺晴康, 斉藤 進 : 唇頡口蓋裂患者の補綴的修復につい て，顎顔面補綴， $7: 64 \sim 65,1984$.

9）岸本康男, 田中貴信, 石上友彦ほか：当科における口唇, 口蓋裂患者の補綴治療に関する臨床統計的観察, 顎顔面補 綴, $15: 1 \sim 10,1992$.

10）三浦不二夫：唇顎口蓋裂一矯正の立場からみた問題点, 顎 顔面補綴, $4: 1 \sim 16,1981$.

11）河野正司, 鳥山秀行, 吉田恵一ほか：平衡側咬頭障害の発 
現機構に関する一考察，補綴誌，32：505〜 513, 1988.

12) Henry, P. and Tan, A. : Prosthodontic implications of the adolescent cleft palate patient, Aust Dent J, $30: 104$ $\sim 111,1985$.

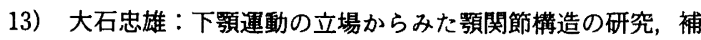
緅誌, $11: 197 \sim 220,1967$.

14) Kantorowicz, G.: Bridge prostheses for cleft palate patients-An analysis, Brit Dent J, $5: 91 \sim 97,1975$.

15) Ohyama, T.: Prosthodontic considerations for patients with cleft lip and palate, Int Dent J, $36: 140 \sim 145,1986$.

16）鈴木るり, 大内 昇, 大山喬史ほか：当科における口唇口 蓋裂患者の補綴処置について 第二報 補綴処置の実際と その遠隔成績, 日口蓋誌, $17: 123 \sim 135,1992$.

17）福原博一, 原 久永, 伊藤学而ほか：唇額口盖裂患者にお ける上䫑菡列弓拡大後の歯列弓幅型と側方菌部逆被蓋の後 戻り, 日口蓋誌, $19: 88 \sim 99,1994$.

18）武藤祐一, 大橋 靖, 花田晃治ほか：唇額口盖裂患者に対
する頻稪正手術の問題点について，額変形誌， $9: 3 \sim 5$, 1990.

19）大山喬史：わが国の唇顎口蓋裂医療の問題点一6)，補緅治 療における問題点, 歯界展望, $51: 551 〜 563,1978$.

20）田中貴信，平沼謙二：唇䫛口蓋裂患者の補綴治療，顎顔面 補綴, $5: 72,1982$.

21) Hotz, M. and Gnoinski, W. : Effects of early maxillary orthopedics in coordination with delayed surgery for cleft lip and palate, J Maxillofac Surg, $7: 201 \sim 210$, 1979.

22) Perko, M. : Two-stage closure of cleft palate, J Maxillofac Surg, $7: 76 \sim 80,1979$.

23）大橋 靖：口唇口蓋裂治療に用いる床装置とその機能，日 口蓋誌, $18 ： 338 \sim 350,1993$.

24）神成庯二：両側性唇額口蓋裂児の影発育に関する研究一 Hotz 床併用二段階口蓋形成手術例について一， 口科誌， $43: 423 \sim 439,1994$. 